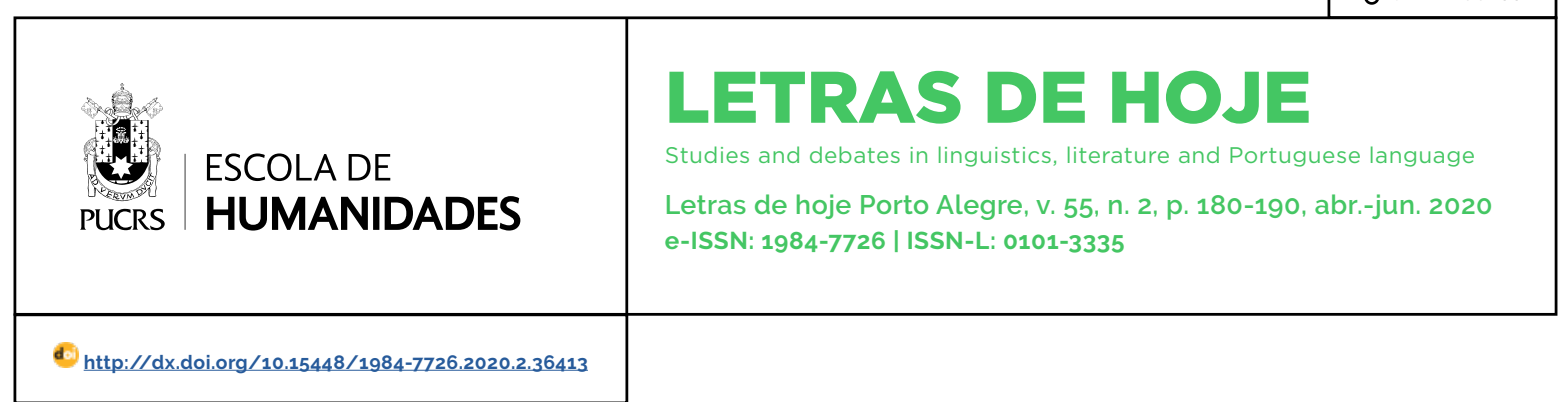

SEÇÃO: TEMÁTICA LIVRE

\title{
A saúde amorosa de Nanda
}

Nanda's loving health

\section{La salud amorosa de Nanda}

\section{Cesar Marcos Casaroto Filho $^{1}$}

orcid.org/0000-0003-1231-6507 cesarcasarotofilho@gmail.com

Recebido em: 12 nov. 2019. Aprovado em: 9 abr. 2020. Publicado em: 11 Set. 2020.

\section{(c) (1)}

Artigo está licenciado sob forma de uma licença Creative Commons Atribuição 4.0 Internacional.
Resumo: No presente artigo, pretendo analisar a ética de Nanda por meio da intriga de Controle, obra de Natália Borges Polesso. Narrado em primeira pessoa pela personagem Maria Fernanda (Nanda), o romance psicológico expressa o drama existencial que coloca em contraste uma Nanda desconhecida de si mesma, ressentida com a vida, com uma consciente de si mesma, desejosa de viver. Palavras-chave: Controle. Sexualidade. Afeto. Potencialidade.

Abstract: In the present article, I intend to analyze Nanda's ethics through the Control intrigue, by Natália Borges Polesso. Narrated in the first person by Maria Fernanda (Nanda), the psychological novel expresses the existential drama that sets in contrast a unknown to herself Nanda who is resentful of life and a self-conscious Nanda willing to live.

Keywords: Control. Sexuality. Affection. Potentiality.

Resumen: En este artículo, tengo la intención de analizar la ética de Nanda a través de la intriga de Control, por Natália Borges Polesso. Narrada en primera persona por el personaje de Maria Fernanda (Nanda), la novela psicológica expresa el drama existencial que pone en contraste a una Nanda desconocida para ella, resentida por la vida, con una Nanda consciente de sí misma, dispuesta a vivir.

Palabras clave: Control. Sexualidad. Afecto. Potencialidad.

\section{Introdução}

O romance psicológico de Natália Borges Polesso, Controle (2019), narrado em $1{ }^{a}$ pessoa pela gaúcha Nanda, protagonista que, pela narrativa da própria vida filosofa sobre o seu espaço e ação no mundo, reflete sobre metamorfoses que, ao se contraporem a uma Nanda ensimesmada, hostil com as pessoas, especialmente com os pais, contribuem para a tessitura de um autoconhecimento que, por sua vez, fica expresso no complexo ato de narrar, com todas as suas idas e vindas, desenhado por meio de uma forma poética que busca por certa logicidade frente ao caos das paixões humanas. Ao florescer sexualmente, pois trata-se de corpo antes de mais nada, Nanda passa a sentir e a pensar de uma outra forma que não aquela que controlou - daí o título da obra - os movimentos espontâneos dela por muito tempo. Há ainda uma "raiva", várias vezes reiterada na obra, que serve de refrão do mal-estar que faz Nanda sentir-se isolada dos demais, ignorando que seu distanciamento 
das outras pessoas é resultante do fato de ela não buscar por potência de vida. Nanda ignora que a letargia que sente é resultante dos próprios pensamentos, do isolamento ensimesmado que a impede de olhar de uma forma estética para as coisas. Mas é contestando o seu estilo de vida letárgico que Nanda pode matizar de outro modo a forma de encarar a vida. Se, dos pais, ressentida, dependeu até os 30 anos sem, na famosa expressão popular, "levantar a bunda da cadeira", comportando-se como uma "bizarra" eterna adolescente, agora, ao deparar-se com a sua fraqueza e arrogância, Nanda pode olhar para as coisas de um modo mais analítico, objetivo, nos limites das possibilidades.

\section{Melancolia e dispersão}

Nanda está cindida de si mesma. Ora, sabemos que o filósofo Benedictus de Spinoza (2017) considera o homem como o ser a que as afecções do pensamento - a propriedade do pensamento é o que o diferencia, enquanto homem, dos outros seres - são simultâneas as do corpo, ou seja, "quando a mente é tomada de algum afeto, o corpo é, simultaneamente, afetado de uma afecção por meio da qual sua potência de agir é aumentada ou diminuída" (SPINOZA, 2017, p. 275), o que resulta em potência de vida, ou alegria, quando aumentada, e em letargia, melancolia, quando diminuída. No entanto, "a ideia de uma afecção qualquer do corpo humano não envolve o conhecimento adequado do próprio corpo humano" (SPINOZA, 2017, p. 121), afinal de contas, não sabemos quase nada do mistério do nosso corpo. Mente e corpo, portanto, "são um único e mesmo indivíduo [...]" (SPINOZA, 2017, p. 115). O fato de Nanda declarar estar cindida de si mesma é decorrente de não conhecer a si. Assim, preocupada, ansiosa, desacomodada na vida, Nanda está perdida/apartada de si mesma. Nas palavras dela:

É estranho que o tempo das preocupações possa ser desordenado assim. Que elas desçam e se instalem nas curvas do nosso intestino mais que na nossa cabeça. Mas quando estamos separados, cindidos de nós, quando eu não sei dos meus desejos imediatos, como posso entender a urgência do outro? (POLESSO, 2019, p. 11).
Refletindo sobre si, Nanda está ciente de que o seu ensimesmamento foi resultante de um descontentamento de si mesma. Ao relembrar de um passeio de bicicleta que fizera com o intuito de "oxigenar as ideias", Nanda é enfática:

\begin{abstract}
Mas o ar não entrava. Só passava por mim. Tudo apenas passava por mim. Nada me tocava. Era aquele descolamento de novo. Uma vontade de sacudir as pessoas, de bater, de perguntar se não estavam sentindo todas aquelas coisas. toda aquela vontade de viver que não podia ser alcançada, se não sentiam na pele e por dentro (POLESSO, 2019, p. 15).
\end{abstract}

Há vontade de vida controlada no corpo de Nanda. A raiva é sintoma dessa enfermidade letárgica. Desconhecendo o que perdeu, Nanda resta melancólica. Vale lembrar que, do ponto de vista da psicanálise, o sujeito melancólico, ou "neurótico narcísico" (FREUD, 2011), diferentemente do enlutado, não sabe nominar aquilo que perdeu; ou seja, o melancólico, depressivo em termos psicanalíticos, de sentimentos e de pensamentos fragmentários, sem perspectiva de contornos, perdeu a si mesmo. Para a psicanalista lacaniana Marie-Claude Lambotte (1997), o melancólico se sente desvitalizado justamente porque não consegue sentir a si mesmo; é como se se tratasse de outrem, jamais dele mesmo. Assim, o melancólico sente-se uma fraude enquanto indivíduo.

No entanto, não é meu intento definir Nanda como uma melancólica ou uma depressiva, afinal de contas, isso seria reduzir a personagem por meio de um psicologismo, o que não é possivel na obra. Gostaria somente de apontar que estados melancólicos também existem nela enquanto algo que a paralisam, mas que, no entanto, permitem a ela sentir intensivamente a sua mudança, já que é a insatisfação que sente diante de tal condição (a de descolamento de si) que a impulsiona continuamente para a mudança. Relaciono, na verdade, a melancolia e Nanda levando em consideração a melancolia enquanto carência própria do caráter humano (LIMA, 2017), afinal, é essa falta essencial, esse vácuo de si próprio da melancolia inerente ao homem o que impulsiona para a mudança. Portanto, não compreendo aqui a melancolia enquanto um 
caso clínico de Nanda, mas, de maneira mais ampla, enquanto dor existencial. Assim, Nanda está sempre em metamorfose, a sua complexidade é demasiadamente humana, suscetivel às mais diversas afecções, em termos spinozistas, tanto às afecções que contribuem para que o ser persevere no ser quanto às que diminuem a sua potência.

É ao se acidentar, quando em um passeio de bicicleta, que Nanda, ao se sentir entranhada de mundo, "tostada" pelo sol escaldante, ao se fundir com o mundo, se dá conta do desejo de viver que habita nela.

Com a voz, a narradora:

Meus braços doem. Será que consigo me levantar? Se apoio as duas mãos neste asfalto, acho que consigo. Meu joelho tá fodido. Dá pra ver daqui, mesmo com os olhos fechados, dá pra sentir que deu uma esmigalhada. Se começo a rir, vão me achar louca, mas tenho uma vontade incontrolável de gargalhar e gritar. Porque agora me dou conta de que entrei na vida, aos tombos mas entrei. Quebrada, entrei. De novo. Aposto que cheguei tarde, mas é tudo meu agora. Meu palco. Meu chão (POLESSO, 2019, p. 16).

A coloquialidade do estilo poético de Polesso exubera a potência da personagem de pensamentos profusos e vulcânicos. Nanda é uma potência encapsulada, há nela um esbanjamento de vida; a força com que narra é prova disso. Nanda elucubra que sempre se sentiu à parte na vida, afinal, "tudo" passou melancolicamente por ela sem tocá-la. Nanda tinha pavor da vida:

Era pavor da vida tão complexa, tão completa. Eu não consegui entrar na vida. Fiquei de fora olhando os eventos pela janela, num aquário impossivel ao lado do mar. Marcando presença e não aparecendo. Marcando presença e desaparecendo. Assisti às coisas todas. Meio boba. Quando deveria ter sido a protagonista, desapareci pra comer pipoca murcha na plateia de um filme tosco, de quinta. Não que eu quisesse, eu não conseguia tomar as rédeas (POLESSO, 2019, p. 17).

Consciente no presente de que não se sentia parte do todo, Nanda reflete sobre o seu pavor. Para Spinoza, o pavor é um afeto que, relacionado à tristeza, um afeto ruim, impossibilita a nossa potência de agir para modificarmos a realidade que pensamos estar colocada em nós de antemão. Para o filósofo, "o pavor diz-se daquele cujo desejo de evitar um mal é refreado pela admiração pelo mal que teme" (SPINOZA, 2017. p. 255), ou seja, "o pavor é, assim, uma espécie de covardia. [...] [É] o medo que mantém o homem tão estupefato ou hesitante que ele não pode evitá-lo" (SPINOZA, 2017, p. 255). A narradora diz que "foi medo": "Eu sempre quis muito viver. Foi medo. Foi falta de prática, foi falta de manha. Foi tanta coisa a menos" (POLESSO, 2019, p. 17). O medo, por sua vez, explica Spinoza, "é uma tristeza instável, surgida da ideia de uma coisa futura ou passada, de cuja realização temos alguma dúvida" (SPINOZA, 2017, p. 243). Daí o fato empiricamente comprovado de o medo e a esperança, essa que vive também de futuro ou passado, andarem de mãos dadas.

Mas são as "sombras", os fantasmas de Nanda que a rondam desde a infância que a encapsulam do encontro direto com a vida:

Porque eu sempre vi umas sombras que me faziam ter medo de tocar nas coisas reais. Essas sombras vivas que me rodeiam como cápsulas e proteções e impedimentos e nãos e cuidados e vontades desdenhadas. E agora o mundo me invade, me força, me roça (POLESSO, 2019, p. 18).

O lirismo do estilo de Polesso, especialmente ao final do excerto, com aliterações que expressam o embate com a vida, a saber - "invade", "força" e "roça" -, contrasta com o encapsulamento, afinal, já não está mais encapsulada, o que o estilo profuso da narrativa de Nanda facilmente comprova. Com medo e pavor, o mundo para Nanda foi sempre hostil. A hostilidade da vida, no entanto, foi fruto da sua imaginação confusa.

O pensamento hostil que se soma a um sentir truncado provém de um desalojamento de si consigo mesmo causador da angústia que Nanda sente. Ela não está nela mesma e, nessa condição, seus pensamentos são confusos, hostis, desarticulados do seu desejo imediato.

Mas Nanda, acidentada, deseja o sol em reiterados enunciados:

Agora tá quente e eu sinto o sol queimar a minha cara, o meu pescoço. Eu quero este sol. Eu quero dentro. Quero que me queime os miolos. Cozinhe mais um pouco o meu cérebro, se ele ainda não estiver cozido. Quero que o sol faça 
evaporar os pensamentos encharcados dessa coisa triste e gosmenta que eu tenho dentro e que vaza, às vezes pros meus cabelos escorridos, oleosos. Quero que ele faça evaporar também das lembranças, essa nata de medo que as envolve (POLESSO, 2019, p. 20).

Nanda deseja a potência do sol para clarear suas ideias das coisas. O medo da vida impede o calor do astro nos movimentos do pensamento. A coisa triste e gosmenta, substância sem forma ou cor, que é senão seus sentimentos emaranhados? Tombada no asfalto, Nanda dá-se conta de si mesma: "Sinto umas faíscas começarem na parte de trás do meu crânio. Espasmo. Mas é apenas susto de mim mesma. Susto de tocar o que sou por dentro." (POLESSO, 2019, p. 21). Em estilo que dialoga com o de Clarice Lispector, Nanda vislumbra em seu desassossego sensivel o susto de se tocar por dentro, de ter nas mãos a matéria mole no interior da barata. Recordemos G.H.:

Eu, corpo neutro de barata, eu com uma vida que finalmente não me escapa pois enfim a vejo fora de mim - eu sou a barata, sou minha perna, sou meus cabelos, sou o trecho de luz mais branca no reboco da parede - sou cada pedaço infernal de mim - a vida em mim é tão insistente que se me partirem, como a uma lagartixa, os pedaços continuarão estremecendo e se mexendo (LISPECTOR, 2009, p. 64).

Nanda compreende-se movimento. Em casa, após medicar-se, a jovem Nanda dá-se conta do seu movimento no nada, já que se sente integrada com a natureza como um todo:

[...] eu era oitenta por cento bactérias, ouvi a voz da professora na aula de ciências, eu era o chão, ânsia de vômito, estava feliz com todas as coisas animadas e inanimadas da face de Terra, que era mesmo um planeta fascinante girando num vasto nada cheio de outros planetas, estrelas e sujeira, no fim éramos todos e tudo the noise that surrounds [grifo do autor] o vômito de Deus, girando em direção a um ralo existencial, buraco negro ao contrário, éramos um grande nada girando no tudo, o movimento incessante de cada célula reproduzido ad infinitum [sic] por todas as galáxias, o mesmo movimento que ia e vinha do meu estômago pulsando energia cósmica [...] (POLESSO, 2019, p. 36)

Afinal, desde jovem a personagem é sensivel ao mundo que a cerca. Não se trata de um antes e um depois, pois os instintos de Nanda sempre existiram, embora, antes daquilo que chamo de seu florescer, antes da consciência que tomou de si mesma enquanto ser humano suscetivel à falha, ela não tenha se permitido ouvir os próprios afetos. À medida que Nanda ignora o seu desejo imediato, perdida está no emaranhado das suas paixões, e então ela não pode tecer nenhuma ideia sobre si ou o outro. A composição poética é o que torna a vida de Nanda uma obra de arte, pois trata-se de algo sensivelmente orquestrado.

Nanda encapsulou-se em sua doença, a epilepsia. Àépoca em que descobriu a doença Nanda admite haver se comportado como uma "criança". Para justificar a tese, a narradora expõe dois argumentos: "[...] primeiro porque meus pais me tratavam com cuidado excessivo e, segundo, porque eu sabia fazer a minha chantagem também" (POLESSO, 2019, p. 44). Nanda não sabe se, nessa fase, foram seus amigos que dela se afastaram ou vice-versa. Nessa época, Nanda compra "fones grandes", a fim de se isolar do contato humano. Ao afirmar ter sentido naquele periodo ser um peso para a familia, devido aos fatos de ter ataques nervosos constantes, não trabalhare de os medicamentos serem caros demais, Nanda reconhece: "Eu tinha me tornado uma pessoa apática e agressiva. Ninguém gosta de lidar com problemas e, como eu parecia ser um, optava sempre pelo revide" (POLESSO, 2019, p. 45). O sentimento de estranheza que vive em relação a si mesma, devido em grande medida à doença, somado ao fato de não conseguir expressar verbalmente o seu malestar, podem ser considerados causas da raiva e da hostilidade de Nanda em relação aos outros, especialmente aos pais. Nanda chega a afirmar não saber se teria sido amiga daquela que foi: "Crises, remédios. Que pessoa chata eu era. Não sei se me suportaria. Não sei se eu mesma seria minha amiga" (POLESSO, 2019, p. 83).

No tempo em que, apática e agressiva, engolia os comprimidos calmantes enquanto assistia aos pais arruinando o casamento, Nanda não sabia que podia desabafar com outrem o que sentia: "Nunca tinha me dado conta de que poderia falar sobre aquilo, sobre aquelas coisas que eu sentia." (POLESSO, 2019, p. 46). O drama da Nanda adolescente pode ser resumido pelo seguinte excerto: 
Eu ouvia "Blue Monday" e "Ironic" sem parar, desejando que ninguém mesmo me perguntasse como eu me sentia, porque eu me sentia uma bosta, uma inútil, alguém que não era normal [...] Porém, eu esperava que alguém me desse atenção, que me perguntasse como era de repente perder a consciência numa descarga elétrica cerebral, como era por dentro para mim, mesmo que eu não soubesse dizer. Queria que alguém perguntasse de um jeito honesto. Porque às vezes a gente não sabe mesmo como se sente, não sabe de nada, nunca por completo, mas seria bom falar sobre isso realmente (POLESSO, 2019, p. 51)

Contudo, enquanto todos parecem ignorar Nanda, Joana, a amiga por quem Nanda é apaixonada - mas ignora o fato por longo tempo -, é a única que, pensa Nanda, a escuta: "Eu não era burra. Eu queria falar sobre as coisas. Eu precisava falar sobre as coisas. Mas todos preferiam ignorar. Menos a Joana" (POLESSO, 2019, p. 51). O fechamento de Nanda com relação ao mundo é consequência da raiva que sente de todos e da condição que forjou para si mesma culpando a doença: "Meus fones de ouvido se tornaram fortalezas impermeáveis. Se o mundo não me ouvia, eu também não queria ouvir nada do mundo. Eu tinha raiva. Escrevia no meu diário com uma letra pequena, apertando o grafite na folha, que eu tinha raiva" (POLESSO, 2019, p. 5354). Das lembranças de Nanda com relação aos pais discutindo sobre o "peso" da filha chantagista: "Ouvia os dois discutindo o peso da filha abobada. O peso da filha mau-caráter. O peso da filha. Nem eu sabia me definir. Nem queria" (POLESSO, 2019, p. 55). Na parte em que recorda a insistência da mãe em ir com ela ao shopping, programa que Nanda detesta, a narradora expressa:

Irritações começaram a crescer em mim como formigas debaixo da terra construindo um grande formigueiro, prestes a ser pisado por uma alma desavisada. Meus olhos escureceram, minha pele começou a arder e minhas mãos gelaram completamente. Era raro eu não conseguir de primeira o que queria (POLESSO, 2019, p. 56).

Nesse período, o pensamento fixo de Nanda é de que será "sempre assim"; não há possibilidade de mudança:

Talvez eu tivesse uma doença demoniaca, porque eu estava me tornando uma pessoa ruim. mentirosa. Olhei para a minha cama, estava pegando fogo, cogitei deitar e queimar junto. Mas era delírio, imaginação. Minha cabeça martelava muitas ideias, e estagnou em uma: vai ser sempre assim (POLESSO, 2019, p. 57).

Ora, um pensamento que limita qualquer ação ou nova perspectiva para a vida é imobilizante. Naturalmente, sob uma lógica absurda, Nanda não pode se sentir de outro modo que não como se dentro de um contínuo estado de mal-estar com relação a si e aos outros. Encerrada em si mesma e preocupada unicamente com os próprios problemas, Nanda convalesce de uma raiva e de um medo de viver que fazem vingar pensamentos obscuros e desarticulados. Quando sua mãe the pergunta do que sente raiva, Nanda responde: "Das pessoas. De mim mesma. Sei lá. É muito, sabe? Eu preciso esvaziar" (POLESSO, 2019, p. 58): e, assim, Nanda se desculpa com a mãe por ter fingido um ataque epiléptico no shopping. A Nanda adolescente tem consciência de que a raiva a faz agir de uma forma ruim. Ela sente-se adoecida em relação ao seu trato social. A sua convivência está doente.

Acima de tudo, Nanda não se sente parte do contexto familiar, o que lhe é fonte geradora de forte sofrimento. Estrangeira em relação aos familiares, Nanda sabe que as primas a tomam por bizarra. É desse modo que Nanda expressa a sua falta de identidade: "Eu fugi. Fugi daquilo tudo, da cena, das outras fotos e viagens que vieram. Mas foi porque eu não me sentia parte. Não tinha fotos de viagens, não tinha fotos de idas ao parque, às cascatas, às piscinas, às fazendas, ao estádio de futebol." (POLESSO, 2019, p. 65). Nanda aqui está em fuga, mas em busca, e daí sua insatisfação na procura por contornos que the deem certa segurança e leveza nos gestos. Em seu modus operandi paralisado frente ao movimento do mundo porque confusos e atemorizados os pensamentos, Nanda sente um machucado que não sara, ferida exposta causadora da sua raiva: "Eu fiquei quieta por anos, assistindo brigas imensas, vendo gente se afastar. Se dar bem na vida. Ter filhos" (POLESSO, 2019, p. 68). Consciente de que a vida é, como a massa esbranquiçada e grossa da barata (LISPECTOR, 2009), "essa 
substância, massa amorfa, espalhada, rala num canto, densa noutro" (POLESSO, 2019, p. 68-69), a jovem Nanda busca pelo entorpecimento, ignorando a possibilidade de dar uma forma poética - para o seu sofrimento, já que

Essa lava crescia desajeitada e sem espaço dentro de mim. Não parecia fácil me livrar da dor, nem da vontade de matar meio mundo. Mas eu socava tudo goela abaixo, junto com a medicação. E depois me alienava durante horas na frente da tevê, na frente do computador, com a cabeça enfiada dentro de revistas, porque ali eu era passivamente alimentada, me espaçava, me anulava (POLESSO, 2019, p. 69).

Ora, a subjetividade de Nanda é pasteurizada pela sociedade, dadas as diferenças históricas, da "reprodutibilidade técnica", aquela que, para Walter Benjamin (2013), padroniza subjetividades amortecidas pelo que o capitalismo religiosamente oferece como forma de preencher (ou esvaziar ainda mais) a falta essencial do homem. 0 capitalismo, nessa perspectiva, promove uma espécie de paródia do projeto religioso de reforma da alma humana. A "viscosidade psíquica", termo cunhado por Giorgio Agamben (2009) para pensar o fenômeno psíquico do sujeito pós-moderno que sofre da uniformização de subjetividades promovida em grande parte pela mídia, vem bem a calhar no contexto de Nanda. Que faz a personagem com a ajuda tecnológica senão entorpecer os seus reais desejos?

À Joana, Nanda conta as suas incompreensões e anseios de "independência". Diz essa àquela:

Não. Eu preciso poder ser sozinha. Eu não sei o que é isso, Joana, entende? Ser independente. Não precisar que ninguém fique olhando se eu não vou cair no chão sem conseguir limpar a minha própria bunda, será que eu vou poder morar sozinha, ter uma vida besta, simples, normal, será que eu vou poder ter um gato ou um cachorro [...] (POLESSO, 2019, p. 71).

Ocorre que independência aqui não é apenas assumir a administração da própria vida, mas algo mais básico, já que, conta Nanda à Joana, precisou que os pais limpassem a sua "bunda" após um dos seus ataques. Tal limitação (tão básica) é um fantasma que impossibilita que Nanda imagine um bom futuro para si, um futuro "normal", afinal, ela é "bizarra". Além do básico, a nível cultural Nanda anseia pelo lado "selvagem" da vida, fora do seu encapsulamento de nãos e restrições. No entanto, ela tem uma imagem horrivel de si mesma: "Eu tinha uma imagem muito distorcida de tudo. Eu tinha uma imagem horrivel de mim" (POLESSO, 2019, p. 78). Com os pensamentos turvos e o isolamento, Nanda desarticula-se das conversas, do contato humano: "Eu gaguejava e algumas palavras me fugiam quando a frase era longa. Mas nem sei se a causa era a epilepsia, os remédios, ou se era só eu mesma, que não estava acostumada a conversar" (POLESSO, 2019, p. 83).

Quando relembra de um trabalho de aula em que deveria ter escrito um diálogo com um duplo, a fim de que, com isso, descobrisse algo sobre si mesma, Nanda se dá conta do quão "chata" havia se tornado nessa dinâmica de vida de "crises e remédios". Assim Nanda expressa o seu insight: "Cara, como eu era chata. Que tipo horrivel de pessoa eu tinha me tornado" (POLESSO, 2019, p. 84). Em uma consulta com o psiquiatra que ela era "obrigada a ver", Nanda confessa não estar apaixonada pelo paulista Antônio, o seu namorado "da internet", e que também não tem vontade alguma de sexo. Vale destacar que do ato sexual com outrem Nanda impediu-se até os 30 anos; a única experiência sexual da balzaquiana até a idade é online, com o Antônio. Por meio da memória de quando fora questionada pelo médico se não sentia "borboletas na barriga", a narradora assim tece a velha Nanda:

Eu poderia ter borboletas na cabeça. Borboletas que bagunçavam tudo e depois regrediam para a forma de casulos até que estes eclodissem soltando um monte de lagartas feiosas, perigosas, que deixariam um rastro de queimadura por tudo (POLESSO, 2019, p. 89).

As lagartas perigosas e feias do seu sentir só fazem relações de pensamentos hostis à época em que Nanda se vê de maneira distorcida. A distorção do real é comum a um pensamento confuso das próprias potencialidades. A sexualidade de Nanda não tem direção, os seus movimentos estão estranhamente controlados. O jugo da Lei proíbe Nanda de ocupar outro lugar que não o 
do reino de um passado ou de um futuro ideais. Nanda é prisioneira das próprias fantasmagorias. A imaginação distorcida de si e do mundo molda-lhe uma realidade pobre em que se encontra insatisfeita. Trata-se de um envenenamento psíquico, uma asfixia dos sentidos, uma incapacidade de tornar as ações dinâmicas, fluidas. Na voz de Nanda: "Eu estava cansada de ter aquela vida limitada e ver meus amigos realizando coisas enquanto eu corria em círculos de asfixia para chegar a lugar nenhum" (POLESSO, 2019, p. 88).

O vazio existencial e o medo dele são uma constante para a jovem Nanda. O não saber o que fazer do vazio levam-na um dia a atribuir a si mesma um diagnóstico que the serve de atributo: deprimida. Assim dizem as memórias ficcionais de Nanda:

Fiquei pensando nesse vácuo dentro de mim. Um nada que crescia e me deixava com medo. Colei os olhos na parede. Cai no meu imenso vazio. Como eu poderia preencher a minha existência? Estava ficando cada vez mais deprimida. Foi a primeira vez que me atribui a palavra: deprimida (POLESSO, 2019, p. 88).

Felizmente, o psiquiatra de Nanda, frente ao drama do vazio relatado pela personagem, chama-a idiota. Nas palavras de Nanda: "Até que ele disse uma coisa que me acertou bem no meio da cara: já parou pra pensar que existem muito mais pessoas no mundo que têm a mesma coisa que tu e não agem assim como idiotas" (POLESSO, 2019, p. 90). Nanda fica "estarrecida" com o fato de o seu médico a achar uma "idiota". Nanda sabe que é "insuportável". Até que um dia se dá conta: "Por que eu não tinha um trabalho? Nunca tinha me passado pela cabeça e me agradou muito a chance de mudança" (POLESSO, 2019, p. 91). Exercer uma função foi uma possibilidade que a deixou animada. Após contar aos pais a decisão de começar a trabalhar aos 27 anos, afinal de contas, até aí nunca os ajudara com as contas da casa, assim Nanda diz ter se sentido: "Uma coisa simples, parecia que a partir dali as coisas poderiam mudar, andar em outro ritmo. Eu sentia, sentia uma coisa boa crescer dentro de mim" (POLESSO, 2019, p. 93). Nas horas de trabalho de "secretária no consultório pediátrico da Jaque", Nanda afirma ter podido se sentir existir:
"Durante aquelas horas, a sensação de normalidade me aliviava. Eu podia existir. Ali eu exercia uma função e aquilo me deixava animada" (POLESSO, 2019. p. 93). No trabalho, Nanda, sentindo-se útil, encontra ânimo para viver.

Contudo, se no trabalho Nanda vislumbra algum conforto, no amor, com Antônio, as coisas não vão bem, afinal, após dois anos de namoro, nunca haviam se tocado. Nanda se dá conta da idealização que é o seu namoro e da impossibilidade que há nisso, especialmente porque marcado pela distância física. Novamente é o controle a lhe fazer impossibilidades no existir: "Não sabia que espécie bizarra de controle eu tinha sobre mim mesma que me fazia não viver, não experimentar" (POLESSO, 2019, p. 102). Sem tocar o real, Nanda sufoca. Conta-nos a narradora que a Nanda de 30 anos, ao se dar conta do controle bizarro que tinha sobre si, chora profundamente: "Não lembrava de ter chorado daquele jeito nunca na vida. Até ali, naquele ponto da minha vida, aquele choro tinha sido recalcado até o último pedacinho de desejo de saida" (POLESSO, 2019, p. 102). É de uma crueza fatal o seguinte parágrafo: "Eu chorava coisas velhas, chorava proibições construidas, fantasmas, anos perdidos, terras não pisadas, a rapidez do tempo, a ausência do amor." (POLESSO, 2019, p. 103). E então, na mesma página:

Chorei o que passou soterrado, arrastado, amortecido pelos remédios, pelo recalque. A virgem de trinta anos. Não é que eu não sentisse, que não tivesse desejos, eu só não sabia administrá-los. Então eu ignorei o tempo, ignorei os ritos. Fui estocando tudo num lugar bem fundo, sem fresta ou possibilidade de fuga. Tudo controlado (POLESSO, 2019, p. 103).

Nanda chora pelas ilusões regidas pelo medo da vida. A caixinha de comprimidos só contribuiu para o fomento da neurótica Nanda, a Nanda que não soube sentir. Então, Nanda "cai na real": termina com Antônio.

\section{0 vitalismo de Nanda}

Na cena em que Nanda recebe agradecimento por ajudar um cachorro que está debilitado, fica evidenciado o significativo gesto espontâneo da 
personagem: "Acho que era a primeira vez que alguém me agradecia por algo que eu tinha feito espontaneamente" (POLESSO, 2019, p. 113). Outra cena em que se evidencia a simplicidade no viver espontâneo soma-se à do cão no mesmo capítulo, "Técnica": após tomar um banho longo, encarar os próprios pelos e "passar a mão" neles, isso antes de jantar com os pais e de conversar com eles "sobre trivialidades", Nanda pensa no extraordinário da simplicidade: "Que dia estranho, que dia extraordinariamente simples" (POLESSO, 2019, p. 115). Os gestos simples e corriqueiros passam aos poucos a não serem mais vistos por Nanda com maus olhos; a arte - ou técnica - de viver ordinariamente, de uma forma menos tóxica, aos poucos começa a se sedimentar em Nanda.

No mesmo capítulo Nanda reflete sobre a compreensão da Nanda no dia em que, voltando de Porto Alegre, após uma consulta médica sobre a necessidade ou não de operar o seu cérebro para que as crises, na melhor das hipóteses, terminassem, tocou - gesto simples, essencial - na mão da mãe, no carro:

Tateei o banco à procura da mão da minha mãe. Encontrei. Sempre encontrava. Estava sempre por perto, pra me virar quando preciso, pra marcar médico, fazer um sanduíche, encomendar um bolo tosco, pra todas as coisas estava ali. A mão dela também tremeu. E o que eu já tinha feito por ela? (POLESSO, 2019, p. 118).

A consciência do próprio egoísmo cai sobre Nanda como um banho de água fria. Contudo, os reclames ensimesmados cunhados sobre a justificativa imaginária de ser um ser humano bizarro e sem memória aparecem em uma cena em que Nanda desabafa para Joana sobre o seu desconforto em viver. Joana, apesar da clareza do argumento que expõe para Nanda contra o exagero e o autocentramento desta, não é ouvida, já que, após alegar: "Eu também tenho minhas questões sobre as quais não sei falar e tenho que achar o caminho, como todo mundo, sabe, o mundo não gira ao redor do teu umbigo. E como acha que eu fico quando a minha melhor amiga não me ouve?" (POLESSO, 2019, p. 121), a cega Nanda passa sobre o último comentário de Joana de uma forma especialmente indelicada:
Fora que a minha memória parece um labirinto fatiado, eu começo num lugar e de repente tô em outro e nem sei por onde passei. Eu não me lembro de grandes periodos da nossa amizade e, às vezes, não sei se algo aconteceu ontem ou há cinco anos. Eu queria que alguém reencenasse a minha vida pra eu poder assisti (POLESSO, 2019, p. 121-122).

Após o dito, o comentário de Joana não poderia ser mais óbvio: "Realmente, tu não me ouve" (POLESSO, 2019, p. 122). Sim, Nanda ainda não ouve ninguém. Como a que se volta unicamente para os próprios problemas poderia amar? Nanda sente-se perdida, naturalmente. E a questão sobre a ignorância dos desejos imediatos que abre o romance retorna logo em seguida: "Eu não consigo nem me ouvir, como vou compreender os outros se eu não sei nem onde eu tô?" (POLESSO, 2019, p. 122). Joana, então, sugere à Nanda que escreva. Mal sabe ela que Nanda já possui um diário e que nele ela escreve justamente sobre o amor que sente pela amiga e, como diz a narradora, "sobre como mantínhamos essa amizade que era profundamente amorosa, e na mesma medida silenciosa, porque não nos dizíamos coisas importantes" (POLESSO, 2019, p. 123).

Quando à amiga Joana declara ser gay e ter um caso com Sara, Nanda busca controlar sua paixão se convencendo de que não se trata de um caso sério: "Era só um nome sem rosto, sem desejo algum. Sara. Nada. Não era nada. Sara" (POLESSO, 2019, p. 125). No capítulo "Interlúdio", em que Nanda rememora quando passou pela intervenção cirúrgica na cabeça, a narradora se embebe de sensações relacionadas a uma Joana que consegue tocá-la mais fundo que o cirurgião. Nanda ama Joana:

Joana afunda as mãos no meu crânio, seus dedos penetram minha cabeça, chegam a lugares escuros, minha câmara fria, Joana chega com os seus dedos dentro de mim, dentro da minha cabeça, Joana toca onde jamais tocarei, onde nem o cirurgião conseguiu chegar. Lá ela chega (POLESSO, 2019, p. 130)

Joana toca o desconhecido de Nanda, e isso é prova do desejo daquela. Nanda está em expansão: aquilo que sente deve ser, de agora em diante, externalizado: "É assim que me sinto. 
Expansão de ondas chocando-se contra o meu corpo e também a favor. Potência energética num colapso gravitacional" (POLESSO, 2019, p. 131). Ora, Nanda só poderá viver de fato as suas afecções se se permitir sentir.

Em um réveillon Nanda resolve enterrar, gesto simbólico, as cartelas que lhe controlam o pulsar da vida: "Tomei uma garrafa de espumante no réveillon. Enterrei todas as cartelas de remédios no pátio, desejei saber que espécies de flores imperturbadas nasceriam. Ao outros, desejei a calmaria daquelas poções. A mim, desejei movimento"2 (POLESSO, 2019, p. 139). Nanda não deseja um estilo de vida medido e doutrinado pelos medicamentos, afinal de contas, é somente no movimento que poderá unir-se ao próprio corpo, às afecções que lhe são próprias. Já não comporta o entorpecimento dos medicamentos o corpo que se decidiu pela expansão.

É pelo embate titânico que deve travar com as próprias forças que Nanda conseguirá encontrar formas novas para si. Nanda demanda para si mesma o próprio centro, a não dispersão em ideias confusas, distorcidas, que the são fonte de um sofrimento inútil, pois gasto ineficaz de força que não a levam, por meio de uma ordenação favorável para que o ser persevere no ser, a um bem-estar: "No centro do centro do mundo. No centro do centro de mim e do mundo no centro de mim o mundo no centro eu no centro do mundo todo em mim eu estava livre. Sorri" (POLESSO, 2019, p. 161). É harmonizando as próprias forças, é dando-lhes novas formas que Nanda poderá se aprimorar como sujeito. Michel Foucault, em sua História da sexualidade: o uso dos prazeres (2017), reflete sobre aquilo que chama "estética da existência", techne de aprimoramento ético do cidadão heleno. Distintamente dos modernos, para o heleno, a obra de arte não apresenta uma cisão com a vida prática do sujeito político. Se para o indivíduo moderno o conceito de obra está desvinculado do cotidiano, do dia a dia, para o heleno arte é a própria existência. Deve-se pensar a si mesmo, conhecer a si, a fim de, esteticamente, aprimorar-se como ser coletivo. Ao pensar a si mesmo, ao refletir sobre as próprias experiências no mundo, o sujeito que se propõe a estetizar a si, tornando-se uma obra de arte, promove uma "ascese", um "exercício de si" (FOUCAULT, 2017, p. 14), um autoconhecimento.

Ora, o que faz Nanda com seu diário e com a narrativa de si (escritura de si) senão uma estetização das próprias experiências, um exercício artístico e filosófico promovedor de um conhecimento de si, um conhecimento compreendido como tal porque, enquanto efeito de uma escritura, suscita reflexões éticas e estéticas sobre o sujeito no mundo? Para Foucault, as estéticas da existência são "tecnologias de si",

práticas refletidas e voluntárias através das quais os homens não somente se fixam regras de conduta, como também procuram se transformar, modificar-se em seu ser singular e fazer de sua vida uma obra que seja portadora de certos valores estéticos e responda a certos critérios de estilo (FOUCAULT, 2017, p. 16).

Trata-se de uma prática de si aqui apresentada na forma narrativa de uma obra de autopoiesis, uma obra que o sujeito faz de si mesmo. Tratase de um autoconhecimento como modo de aprimoramento e transformação de si. Não se trata, contudo, de regras de conduta relacionadas a uma unicidade moral, mas de artes (tecnologias) de si vinculadas diretamente com o sujeito em sua singularidade. Diferentemente do cristianismo, promovedor de uma estética ligada a um regramento moral cujo objetivo é a uniformização das condutas singulares, a estética da existência diz respeito a uma cultura de si, uma arte que o sujeito promove dados os conhecimentos que obtém ao refletir sobre as próprias experiências; portanto, uma arte não aplicável universalmente. O filósofo contrapõe o texto doutrinário da Lei com a techne, a prática de si, o savoir-faire, que, ao levar em conta os principios gerais de conduta ética em sociedade, dado o contexto histórico, guia "a ação no seu próprio momento, de acordo com o contexto e em função de seus próprios fins" (FOUCAULT, 2017, p. 75). Assim,

2 Vale relacionar as "flores imperturbadas" à tela de natureza morta, sem título (1880), de Henri Fantin-Latour, que serve de capa ao romance. A representação das flores mortas pode ser interpretada como uma metáfora do controle que impossibilita o florescimento de Nanda. 
não é universalizando a regra de sua ação que, nessa forma de moral, o individuo se constitui como sujeito ético; é, ao contrário, por meio de uma atitude e de uma procura que individualizam sua ação, que modulam e que até podem dar um brilho singular pela estrutura racional e refletida que the confere (FOUCAULT, 2017, p. 75).

Trata-se de uma forma de controlar os excessos das paixões promovedoras de ressentimentos e outros males que fazem adoecer a psique e o corpo. É porque pensa a si mesma que Nanda tem condições de melhor conviver consigo mesma e com os outros. A saúde de Nanda consiste nisso. E ela deve amar para fazê-lo. É porque pensa a própria sexualidade e as próprias atitudes frente à vida que Nanda pode sustentar os seus desejos imediatos, dando-lhes forma. Não é, contudo, uma hermenêutica de si o que ocorre, mas justamente uma arte de si, uma estética que possui um tom de franqueza porque aqui o sujeito poético está disposto a sustentar o olhar franco do apaixonado, aquele próprio do verdadeiro artista de que fala Benjamin (2013). O estilo franco de Polesso não implica uma verdade absoluta que deva ser seguida tal qual um regramento moral, mas experiências com verdades possiveis, nunca definitivas.

Após assistir a um show do New Order, em São Paulo, Nanda, conversando de uma forma extraordinariamente casual com Gillian, integrante da banda, e isso em um contexto em que viajara com Joana e a namorada desta e em que já havia beijado duas garotas, reflete sobre a "retração", a "autopiedade" e o "medo da vida" que analisou em si: "Acho que a última vez que me empolguei mesmo foi logo depois da construção da pistinha de bicicleta, a primeira volta pra valer que dei. Depois foi sempre medo. Retração. Autopiedade" (POLESSO, 2019, p. 165). Após o show, em um apartamento com duas amigas - Flávia e Bárbara - que havia conhecido no banheiro do aeroporto em São Paulo, Nanda desabafa após Bárbara perguntar-lhe: "Qualé a tua história, bi?" (POLESSO, 2019, p. 168). E assim reflete a narradora: "Qual era a minha história? Precisava contar para entender como eu tinha chegado ali. E contei. Contei tudo" (POLESSO, 2019, p. 168). Foi franca, narrou tudo às quase desconhecidas, até os minimos detalhes sobre o que sentia com relação à amiga... E eis que Nanda, enfim, sabe o que deseja:

\begin{abstract}
Eu queria as mãos da Joana no meu corpo, no meu peito, na minha barriga pra conter o medo, queria as coxas da Joana no meio das minhas coxas, esfregadas, empurradas, abertas, queria molhar a Joana com os meus líquidos, com a minha saliva, com o meu suor, minhas vontades (POLESSO, 2019, p. 170).
\end{abstract}

\section{Considerações finais}

Não é Platão, em O banquete (2019), na voz de Agaton, que diz que Eros, o deus aparecido logo após Caos (o princípio), é sempre jovem, suave e de constituição úmida? Porque é úmido, Eros tem a capacidade de se amoldar a todos os contextos. Ora, diante disso:

\begin{abstract}
Do peito de hábitos duros ele some; peito de hábitos puros ele assume. Toca com os pés, com os braços, brandissimos entre brandissimos. Haverá ser mais suave do que Eros? É extremamente jovem, extremamente doce. O que mais? O corpo, úmido! Fosse seco, não poderia ajustar-se a toda pele, não poderia, evasivo, insinuar-se em todos os corações e sumir (PLATÃO, 2019, p. 77).
\end{abstract}

Como poderia a Nanda seca, dura e melancólica conhecer o amor? Antes de amar Nanda deve abrandar artificialmente, por meio de uma arte de si, o seu autocontrole, de maneira a se permitir, sob o signo já não mais de Saturno, mas de Eros, entregar-se a novos contextos, novos corpos, novas experiências. É pela plasticidade própria de Eros que a nova Nanda, a dionisiaca, deverá amar. Diz ainda Agaton: "Não padece, se é que padece, violência; violência não lhe apetece. Age, quando age, sem violência" (PLATÃO, 2019, p. 77). A raiva incompreendida de Nanda fez impossibilitá-la conhecer a sua forma singular de amar, aquela que deve, conforme o princípio de Eros, recusar a rispidez, a secura ou qualquer tipo de violência contra si e o outro.

Por fim, é o sexo a força de vida de Nanda; ouvi-lo é fundamental para que ela consiga reagir ao controle que the adoeceu o corpo e os pensamentos. Nanda precisa perder o controle ouvindo o seu desejo imediato. Para poder ser ela mesma, Nanda precisa se confrontar com 
seu desejo, com o outro. Nanda busca por vida. Conseguindo visar o seu objeto de desejo, Nanda pode afirmar, na última página: "Não quero estilhaçar" (POLESSO, 2019, p. 172), e isso, antes de citar a si mesma no tradicional discurso direto: "Eu quero viver" (POLESSO, 2019, p. 172). O último parágrafo do romance, composto pelo desejo sexual reiterado de Nanda por meio de citações indiretas do New Order, é fundamental para a comprovação do projeto em perseverar em ser: "Eu quero viver, tenho certeza here comes love it's like honey eu tenho certeza, you're not alone anymore you shock me to the core eu sei we're like crystal we break easy eu quero viver" (POLESSO, 2019, p. 172).

\section{Referências}

AGAMBEN, Giorgio. O que é o contemporâneo e outros ensaios. Chapecó: Argos, 2009.

BENJAMIN, Walter. O capitalismo como religião. 1. ed. São Paulo: Boitempo, 2013.

FREUD, Sigmund. Luto e melancolia. São Paulo: Cosac Naify, 2011.

LAMBOTTE, Marie-Claude. O discurso melancólico: da fenomenologia à metapsicologia. Rio de Janeiro: Companhia de Freud, 1997.

LIMA, Luiz Costa. Melancolia: literatura. São Paulo: Unesp, 2017.

LISPECTOR, Clarice. A paixão segundo G. H.. Rio de Janeiro: Rocco, 2009.

POLESSO, Natalia Borges. Controle. 1. ed. São Paulo: Companhia das Letras, 2019.

SPINOZA, Benedictus de. Ética. 3. ed. Belo Horizonte: Autêntica, 2017.

\section{Cesar Marcos Casaroto Filho}

Cesar Marcos Casaroto Filho é graduado em Letras (2014), pela Universidade de Caxias do Sul, mestre em Letras (2017), pela Pontificia Universidade Católica do Rio Grande de Sul, e doutorando em Letras por esta instituição.

\section{Endereço para correspondência}

Cesar Marcos Casaroto Filho

Pontifícia Universidade Católica do Rio Grande do Sul

Av. Ipiranga, 6.681, prédio 8, sala 403

Partenon, 97010-082

Porto Alegre, RS, Brasil 